\title{
THE MORAL EPISTEMOLOGICAL ARGUMENT FOR ATHEISM
}

\author{
JOHN J. PARK \\ Christopher Newport University
}

\begin{abstract}
Numerous supposed immoral mandates and commands by God found in religious texts are introduced and discussed. Such passages are used to construct a logical contradiction contention that is called the moral epistemological argument. It is shown how there is a contradiction in that God is omnibenevolent, God can instruct human beings, and God at times provides us with unethical orders and laws. Given the existence of the contradiction, it is argued that an omnibenevolent God does not exist. Finally, this contention is defended from several objections.
\end{abstract}

Since the first century CE, scholars have been well aware of the apparent immoral laws and mandates decreed by the Judeo-Christian-Islamic God in numerous religious texts and have attempted to reconcile the seeming discrepancy between the existence of a God who is wholly good and yet has promulgated such purportedly unethical laws and orders. Today, New Atheists use such discrepancies to contend that one should not look to the Torah, Bible, or Quran for moral guidance. However, things will be taken a little further in this paper and such discrepancies will be used to argue for an ontological thesis that God does not exist. While there are positive arguments for God's existence such as the ontological, cosmological, and teleological arguments, a new positive atheistic contention will be offered that is called the moral epistemological argument. It shall be contended that due to the supposed licentious beliefs and purported knowledge that God instructed to human beings through divine revelation, an omnibenevolent God really does not exist. First, the apparently immoral mandates contained within religious texts will be explored. Next, the moral epistemological argument will be given 
and defended. While the moral epistemological argument may seem like a simple and obvious potential argument against God's existence, to the best of my knowledge, it has not been comprehensively and philosophically articulated before. Despite its simplicity, I believe the moral epistemological argument is a strong argument for atheism, it can be properly defended, and it is worth fleshing out. In what follows, I offer its first comprehensive articulation.

No doubt the mandates of God that shortly will be discussed below are at face value considered to be atrocious and nefarious given contemporary moral standards. The supposed immoral aspects of the religious texts have motivated religious scholars for nearly two millennia to attempt to reconcile such passages with the notion of an omnibenevolent God. However, those with an atheistic bent have used such passages to argue that one should not at all times look to religious scripture for moral guidance. In other words, one need not necessarily determine how one ought to act in a given scenario by turning to religious revelations. For example, Bertrand Russell makes such a move in his essay 'Why I Am Not a Christian (1927)'. The philosopher Wes Morriston has written extensively and critically on the apparent immoral mandates of God. However, from such discussions, he does not draw an ontological thesis that God does not exist. Rather, he merely concludes that such passages should not be taken seriously as moral mandates. For example, he states, 'I have argued that the genocide texts should be rejected on moral grounds.' (Morriston 2012: 14) He also concludes that it is highly unlikely that such commands were ever given (Morriston 2009). Other critical philosophers of God's commands such as Louise Antony (2011) and Edwin Curley (2011) also do not draw ontological claims. For instance, Curley's conclusion is only that such problematic passages are not the inspired word of God.

Modern day public intellectual atheists pretentiously known as the Brights or New Atheists have also made similar criticisms of religious texts. For example, Richard Dawkins writes:

The God of the Old Testament is arguably the most unpleasant character in all fiction: jealous and proud of it; a petty, unjust, unforgiving control-freak; a vindictive, bloodthirsty ethnic cleanser; a misogynistic, homophobic, racist, infanticidal, genocidal, filicidal, pestilential, megalomaniacal, sadomasochistic, capriciously malevolent bully. $(2006,31)$ 
Daniel Dennett notes that the Old Testament God is one who 'could take sides in battles, and be both jealous and wrathful' (2006: 206). Christopher Hitchens states that the Canaanites were 'pitilessly driven out of their homes to make room for the ungrateful and mutinous children of Israel' (2007: 99). Sam Harris comments that if the Bible is true, then people should be stoning others to death for heresy, adultery, homosexuality, worshiping graven images, and 'other imaginary crimes'. In fact, putting to death idolaters in our midst reflects 'God's timeless wisdom' (2006: 8).

New Atheists, as public intellectuals, have written exoteric rather than esoteric works, so they have not defended their claims against the use of religious texts as moral compasses from the numerous attempts by religious scholars and philosophers to reconcile the problematic passages in the literature. Moreover, their use of such passages is not to deny the existence of God. It is not to make an ontological metaphysical claim. Rather, such use of the literature is merely for the sake of showing that given God's existence, his divine revelations bestowed upon human beings as presented in religious texts should not necessarily be followed. For instance, Dawkins states, 'All I am establishing is that modern morality, wherever else it comes from, does not come from the Bible.' (2006: 246) Similarly, Harris writes, 'The idea that the Bible is a perfect guide to morality is simply astounding, given the contents of the book.' (2006: 8) This point that the New Atheists do not make an ontological claim concerning God's existence regarding the problematic moral passages is not a criticism of them. For, their purposes in this context are explicitly stated as being non-ontological ones that merely argue that certain religious texts should not be read for moral guidance. Regarding their limited aims, they perhaps could have a strong support for their case if they additionally defended their premises from the numerous objections in the relevant literature from philosophers and religious scholars. However, what will be attempted here is the use of such problematic passages in order to make a new argument for an ontological metaphysical claim that an omnibenevolent God does not exist. An atheistic positive contention called the moral epistemological argument will be offered.

The topic of this paper is an interdisciplinary one. On the one hand, I address a central issue in Philosophy of Religion and Metaphysics concerning God's existence. However, as the examination of religious texts plays a crucial role, religion scholarship also is important here. I believe that philosophers have only just begun to take the issue of God's 
supposed immoral commands seriously. As Michael Bergmann, Michael Murray, and Michael Rea note, 'Despite the interdisciplinary character of the questions [regarding God's supposed immoral mandates], however, philosophers have not been rushing to address the issue ...' (2011: 4) Most of the work has been done by religion scholars.

There are three main general new contributions to the literature from this paper. The first is that I take an old topic concerning the purported immoral mandates of God, and fully theoretically articulate how one may use this as an argument for atheism. ${ }^{1}$ The second contribution is that I address and object to several attempts from religious scholars to reconcile the problematic passages, such as the moral relativism approach. Some of these attempted reconciliations generally have not been discussed by philosophers, and many philosophers may not even be aware of them. Third, at times I provide novel counters against certain attempts to reconcile the problematic passages. To note, I will also address attempts to reconcile the morally problematic passages from philosophers.

\section{THE SUPPOSED IMMORAL GOD}

Although there will be further qualifications later, the scope of the moral epistemological argument for atheism covers the monotheistic Judeo-Christian-Islamic God. The Jewish Torah, which is the first five books of the Christian Old Testament, and the Bible apparently contain numerous instances where God decrees immoral laws and mandates. While Islamists believe that the likes of Abraham, Isaac, and Jesus were prophets, they maintain it is the Quran that the angel Gabriel revealed to Muhammad that is the ultimate revelation of God. This text also contains apparent unethical commands.

For example, in the Old Testament and in the Quran, God allows for slavery and blood vengeance (Quran 61:92; 75:45). In the Old Testament, the law of retaliation in Exodus is 'life must be paid for life, eye for eye, tooth for tooth. It is also hand for hand, foot for foot, burn for burn, wound for wound and bruise for bruise' (Exodus 21:23-24). The death

${ }^{1}$ It is unclear whether Evan Fales offers a conclusion for atheism based on the problematic religious passages (2011). Regardless, even if he does, he does not articulate how the argument will go nor does he spell out the contradiction that is fundamental to the moral epistemological argument. As stated, to the best of my knowledge, I offer the first full articulation of this kind of argument for atheism. 
penalty may be given to those who strike their parents (Exodus 21:15, 17), to homosexuals (Lev 20:13), adulterers (Lev 20:10), idolaters (Deut 13:6-11), and blasphemers (Lev 24:14). For those that break God's laws, it is said that 'The Lord will give you madness, blindness and a confused mind. You will have to feel around in the daylight like a blind man. You will fail in everything you do. People will hurt you and steal from you every day. There will be no one to save you' (Deut 28:28-29).

In the Old Testament, there also are numerous passages where women do not fare well in light of the decrees of God. Women who were found not to be virgins on their wedding night must be stoned to death (Deut 22:13-21). Prostitution by a priest's daughter mandated death by fire (Lev 21:9). In the Quran, women also do not fare well. God directs the inheritance of male children to be twice that of females $(4: 11)$. God orders for the beating of obstinately disobedient wives after one's attempts at admonishing and refusing to sleep in the same bed with them have failed (4:34). Moreover, God provides young female virgins for sexual gratification to those men who reach paradise (55:56; 56:3538; 78:31-33).

While this discussion of supposedly appalling laws and orders given by God may continue for quite some time and are renounced by most modern day theists, God's mandates for war in the Old Testament must also be discussed. God orders Saul to kill all of the Amalekites, women and children. 'Now go, attack the Amalekites. Destroy everything that belongs to them as an offering to the Lord. Don't let anything live. Put to death men and women, children and small babies. Kill the cattle and sheep, camels and donkeys.' (1 Sam 15:3) God commands Joshua on a wholesale and indiscriminate level to attack, kill, and destroy numerous cities and peoples such as in Libnah, Lachish, Eglon, Hebron, Debir, Hazor, and Canaan (Josh 10:40). As God says, 'you must not let anything that breathes remain alive' (Deut 20:16). God commands Moses in regards to Midian, 'Kill all the Midianite boys. Kill all the Midianite women who have had sexual relations. But save the girls for yourselves who have not had sexual relations with a man' (Num 31:17-18). The following passage promotes slavery, rape, and genocide:

When you draw near to a town to fight against it, offer it terms of peace. If it accepts your terms of peace and surrenders to you, then all the people in it shall serve you as forced labour. If it does not submit to you peacefully, but makes war against you, then you shall besiege it; and 
when the Lord your God gives it into your hand, you shall put all its males to the sword. You may, however, take as your booty the women, the children, livestock, and everything else in the town, all its spoil. You may enjoy the spoil of your enemies, which the Lord your God has given you. Thus you shall treat all the towns that are very far from you, which are not towns of the nations here. (Deut 20:10-18)

To note, while philosophers such as Paul Copan have pointed out such facts as that the Israelites in practice did not actually completely annihilate the population of Canaanites (2011), the main point for the aims of this paper is that as James Barr states, 'the problem is not whether the narratives are fact or fiction; the problem is that, whether fact or fiction, the ritual destruction is commended' (1993: 209). The fact that God orders and commends such ethnic cleansing and other immoral acts to occur is what is important for the moral epistemological argument.

Also, notice that in the New Testament, there are also many supposed immoral mandates. Jesus states, 'Don't misunderstand why I have come. I did not come to abolish the law of Moses or the writings of the prophets. No, I came to accomplish their purpose'. (Matthew 5:17) Jesus says that he supports the moral laws of the Old Testament. Furthermore, in the New Testament in the Book of Revelations, after God purposefully wipes out a sizable portion of the human population by causing extreme natural disasters and plagues in which people beg for death due to their suffering but God does not let them die for five months, God commands the four angels of the Euphrates River and 200 million horsemen to kill another third of all humankind (Rev 9:13-15). ${ }^{2}$ If this were to happen today, well over 2 billion people will be killed from the horsemen. All in all, we see that there are numerous apparent immoral mandates contained in the Quran and in the Old \& New Testaments.

\section{THE MORAL EPISTEMOLOGICAL ARGUMENT}

Like the logical problem of evil, the moral epistemological argument is a logical contradiction problem for theism. ${ }^{3}$ There is a contradiction

${ }^{2}$ While some who will be killed are murderers, and thus, if capital punishment is justified, they deserve to be killed by the horsemen, others will be killed because they have different faiths or because they are thieves. A truly omnibenevolent God would not order the capital punishment of people due to the fact that they do not believe in him or that they are thieves.

${ }^{3}$ Only the logical rather than the evidential problem of evil is mentioned here. 
in the fact that God is omnibenevolent, God has the power to provide knowledge of good and evil to human beings, and God at times gives immoral laws to people. To fully spell out the contradiction, God's omnibenevolence means that he has full knowledge of what is objectively right and wrong and that when God provides humans with laws and commands, they always should be moral rather than immoral ones. ${ }^{4}$ Given that God has full knowledge of what is objectively right and wrong and that he has the power to perform divine revelation, when he does provide humans with moral precepts and orders, they must be moral rather than immoral. However, God apparently does not always provide human beings with beliefs of objectively virtuous laws and commands. At times God seemingly gives people maxims of utter depravity and wickedness. The contradiction lies in the fact that some of the purported moral knowledge that is given to humans by divine revelation is at times ethically and objectively wrong. Therefore, the existence of God and the existence of the supposed immoral mandates are incompatible with each other, where given the immoral mandates, we may conclude that the omnibenevolent God really does not exist. ${ }^{5}$ Notice that in order to form the contradiction, one merely needs only one immoral command from God.

It may be understood that most theists will agree with the characteristics of God that are required in the moral epistemological argument. Most theists will think it is an uncontroversial fact that God is omnibenevolent such that God has full knowledge of what is objectively right and wrong and that he should not provide human beings with immoral laws. In addition to omnibenevolence, he also has the power to bestow moral laws upon humans through divine revelation. Of course, one may always in some way deny one of these attributes, which will allow one to escape the moral epistemological argument, and in this sense, the moral epistemological argument is limited. For instance, if one

\footnotetext{
${ }^{4}$ The attribute of having full knowledge of right and wrong is listed under the category of omnibenevolence rather than under some specified knowledge attribute of God since a wholly good being should have full knowledge of right and wrong. Whether having full knowledge of right and wrong should be categorized under omnibenevolence or under some qualified knowledge characteristic of God such as omniscience matters not for the aims of this paper.

${ }^{5}$ Notice that the conclusion that an omnibenevolent God does not exist leaves open the possibility that an evil God exists, just as the problem of evil and the problem of hell do.
} 
believes that God is not omnibenevolent as defined here, then this may be perfectly consistent with the fact that God can provide humans with immoral commands. If God cannot communicate with humans, then despite God's omnibenevolence, he lacks the capacity to instruct people in ethics. Thus, God does not really provide people with commands on how we ought to live our lives, whether they be moral or not. However, I take it that most theists do maintain that God is omnibenevolent in the sense that he has full knowledge of what is objectively right and wrong and that when he gives humans moral commands, he should give morally praiseworthy knowledge. Moreover, most theists will agree that God can communicate with human beings. Therefore, the moral epistemological argument may be taken to be a contention of significant scope.

Notice also that the moral epistemological argument is not to be confused with the problem of evil, even though both arguments deal in some way with right and wrong. On one variant, the problem of evil can also be thought of as a logical contradiction argument against God's existence. It states that there is a contradiction in the fact that God is omnibenevolent, where God attempts to eliminate evil as far as possible, God is omnipotent, and evil exists. Given the supposed contradiction and the existence of evil, the omnibenevolent God does not exist. First, regarding the crucial attributes of God in the two arguments, the moral epistemological argument, in order to formulate the contradiction, primarily requires God's omnibenevolence to mean that God has full knowledge of what is objectively right and wrong and that he should provide people with moral commands whenever he tells people how they should live their lives. While this understanding of omnibenevolence is perfectly consistent with attaching further attributes to the meaning of the concept, for the problem of evil, the primary focus on God's omnibenevolence in order to construct the relevant contradiction is different in that it is mainly used to argue that God is to eliminate the presence of evil as far as possible. Also, the problem of evil requires a significant degree of power for God in order to have the power to eliminate evil as far as possible. Thus, it is said in the problem of evil that God is omnipotent, although there may be certain restrictions to his omnipotence such as not being able to do what is logically impossible. However, for the moral epistemological argument, the measure of power required of God in order to sufficiently make the relevant case is that God has the power to communicate with human beings through divine revelation. It is a much weaker requirement of power for God. Second, 
concerning the non-attributes of God, the problem of evil states that evil exists whereas the moral epistemological argument claims that the purported knowledge that God gives human beings of ethics is immoral and is not really moral knowledge at all. These are two different things, where the former is about natural evil and immoral actions performed between human beings that happen in the world, and the latter is about divine revelation and the supposed moral knowledge that God gives human beings. Notice that one celebrated counter to the problem of evil in order to account for human evil is the free will defence. God creates a greater state of affairs by providing people with the freedom to perform good or evil against each other. If this is the case, then the contradiction formulated by the problem of evil regarding the existence of human evil potentially disappears. However, notice for the moral epistemological argument that even if it is granted that human beings can make free choices, the contradiction in the moral epistemological argument still remains.

Also, the moral epistemological argument can be distinguished from the problem of hell, which is also a logical contradiction argument concluding that God does not exist. The problem of hell generally states that there is a contradiction in God being omnibenevolent, omniscient, and omnipotent and hell existing, where people are consigned to hell forever for eternal punishment (Adams 1993). Such a hell with its infinite punishment is evil, and given God's attributes, God should not have allowed for such a hell to exist. Given the supposed contradiction, we may then conclude that an omnibenevolent God does not exist. Notice the problem of hell states that an evil hell and location exists whereas the moral epistemological argument claims that the purported knowledge that God gives human beings of ethics is immoral and is not really moral knowledge at all. There are potential responses to the problem of hell, such as the universalist reply that hell is only for temporary rather than permanent residence or that there is no suffering in hell. Those who espouse the choice model response contend that hell is not for retributive purposes. Rather, it is for those who freely choose to be apart from God. They may be with God in heaven if they so choose, but they choose otherwise. Notice that even if such potential responses to the problem of hell are true, such responses by themselves will not sufficiently be able to respond to the moral epistemological argument given all the supposed immoral commands in scripture. The contradiction found in the moral 
epistemological argument and in many of God's ethical commands still exists.

As previously stated, while I take it that most theists will understand the attributes of God as listed in the moral epistemological argument to be uncontroversial, such theists may counter that God does not really provide human beings with immoral commands and laws or that such orders can somehow be reconciled with an omnibenevolent God. It is this crucial premise regarding God's omnibenevolence in the moral epistemological argument that will now be defended.

\section{THE MORAL EPISTEMOLOGICAL ARGUMENT DEFENDED}

To note, most sophisticated scholarly work in reconciling problematic immoral passages in religious texts primarily comes from Christian philosophers and scholars, so the potential objections that will be addressed here will come from the Christian perspective, and mention of the Old and New Testament rather than the Quran will be used throughout. While it may be contentious whether Islamists and Jewish believers may make the below evolutionary argument, it may be understood that they may make all subsequently entertained objections, mutatis mutandis, and that similar responses to such objections as the ones provided in this paper may also be given to them mutatis mutandis.

The first important objection that will be examined is the evolutionary or developmental approach primarily championed by Julius Wellhausen but also espoused by others such as Peter van Inwagen (Wellhausen 1885, Arnold 1884, Maurice 1855, Albright 1940, van Inwagen 2011). In respect to the Hebrew Bible, the evolutionary account claims that there is a gradual and progressive development in moral perception for the Israelites. Analogous to the moral development of a child that goes through several stages of development into adulthood, God was a skilful teacher advancing the Israelites to higher moral levels only to the extent that they would be able and ready to receive such moral wisdom given a certain period in their moral development. At various stages, God taught only at the level that the Israelites could comprehend a moral lesson at a given time, but gradually God's moral lessons progressed in wisdom until it reached its pinnacle in the teachings contained in the New Testament. Therefore, there is no perceived inconsistency since the problematic passages in the Bible may be reconciled based on an evolutionary account. 
First, there are highly questionable moral passages in the New Testament as well such as in the Book of Revelations, where it is commended that scores of those who do not worship the one true God but who have different faiths are killed by God (Revelations 9:13-21). Furthermore, recall that Jesus himself states his adherence to the laws of the Old Testament. It does not appear that God's moral teachings are evolving. Second, even if the Old Testament can be viewed as an early stage of moral development, the stated permissibility of revenge killings, rape, slavery, and genocide should never be given by an omnibenevolent God no matter how crude a level of moral development the Israelites were at. Just as one should never tell an unruly child that hitting other children is permissible, one should not tell a young group of Israelites that rape and genocide is permissible. For, imagine that a parent tells a child who is prone to disobedience that it is permissible to strike others including newborn infants, only to instruct him in his teenage years that such acts are morally wrong. Is this an instance of skilful moral direction or a highly questionable cultivation of the ethical? This is clearly an instance of morally wrong instruction, and this conclusion analogously would also hold for the case of God. If the evolutionary account is true, God deserves our righteous indignation for such a reprehensible method of moral teaching. In light of the evolutionary account, the problematic moral commands from God still strikes one as being very morally wrong. To note, while the theist may now claim that God works in mysterious ways, such a move will be addressed at the end of this essay.

Another potential objection is that of cultural moral relativism. Dennis Nineham and Cyril Rodd have generally argued that those in the Old Testament lived in an agrarian, slave-based, patriarchic, and polygamous society vastly different from our own, including in terms of morality (Nineham 1976, Rodd 2001). Now, on the cultural moral relativism view, adherents argue that what is morally true and false is relative to cultures. There is no absolute or universal moral truth at all. There is no independent objective perspective at all from which people or God may judge other cultures' moral systems. Rather the moral system of the Old Testament is true relative to the early Israelites, and the moral beliefs of current theists are true relative to their modern culture. Making this cultural relativist move is further beneficial in that this means modern day theists do not have to abide by the cultural laws of the Old Testament. Now, those who espouse a cultural moral 
relativist position may attempt to escape the contradiction in the moral epistemological argument by claiming that the apparently problematic passages in religious texts are not problematic relative to the Old Testament moral culture. As the moral epistemological argument states that the given problematic passages are universally wrong, those theists who take the cultural relativist route may object to this premise.

While this is an interesting move in order to reconcile certain apparently problematic passages of the Old Testament, contemporary theists who make such a move may potentially only do so by failing to see the wider implications of cultural moral relativism. If moral truth is relative to cultures, then today's theist cannot properly criticize the ethical values of, for instance, Nazi Germany or the practices of slavery in the Antebellum American South. They cannot claim that the attempt of the extermination of the Jewish population in World War II Germany and slavery in the American South was wrong from an objective point of view. They cannot even claim that God would say that the Nazi Germans and slavery are objectively wrong. At most, they and God may claim that such atrocities are wrong relative to their own or a certain culture in a particular period of time, but they are morally correct relative to the perpetrator's culture. However, most modern day theists claim that such acts are objectively morally wrong and that God would say so as well. When pressed appropriately and shown what logically follows from cultural relativism, I take it that most theists will not espouse this strategy. Based on empirical evidence, theists commonly believe in an objective morality, not a relativistic one (Goodwin and Darley 2008). When Jesus says to treat others as you yourself would like to be treated, most Christians believe this to be a universal moral command that is true even for cultures with moral systems that are incompatible with this law for certain situations. When Jesus gave his moral teachings, at the time they were meant for the Jewish people and the early Christians as well as for the Ancient Romans, even though the Romans may be thought to have had a different moral culture. When so pressed, theists generally will understand that God's omnibenevolence means that God has full knowledge of what is objectively morally right and wrong, where it is presupposed that there is an objective or universal morality. If this is the case, then God's omnibenevolence means that when he provides human beings with instruction, it is instruction of what is objectively morally right. However, God at times tells humans to do things that are considered to be objectively wrong. Hence, the contradiction generally 
remains. However, if one still maintains a cultural relativism in light of what I have just stated above, then as previously noted in my discussion of the scope of the moral epistemological argument and of the definition of omnibenevolence that presupposes the existence of an objective morality, such a divine being that has created a world in which there is no objective morality at all falls outside the moral epistemological argument's scope.

Third, theists may take what may be called the 'moral reading approach' They may argue that an individual may pick and choose what moral commands in the religious texts to select based on what is in fact moral. Ethical critics of theism, such as Morriston, may also give this reply. By having knowledge of what is ethically right and wrong, problematic passages of religious texts may be eliminated as being irrelevant, and one may hold only on to those passages of moral commands that are praiseworthy. In this fashion, one may have an appropriate reading of religious texts that lies in accord with what is in fact morally right. This is consistent with many modern day theists also ignoring passages in religious texts that have been shown to be scientifically false. Not everything in religious texts must be taken to heart. Rather, people should ignore the problematic moral passages and focus only on the virtuous ones.

The response is that this does not eliminate the contradiction. God still decrees immoral commands and laws, so the contradiction still persists. It is just that on the moral reading approach, one may ignore such promulgations. However, personally ignoring certain of God's dictates does not mean that God did not make such dictates. Since such dictates supposedly exist, there is a contradiction. The theist then may counter that God did not make such dictates because they were produced merely as a cultural by-product, they were made by a false witness, they were misinterpretations of God's word, etc. The only commands he really made as captured in religious scripture are ethical ones, and any immoral commands are purely fabricated or misinterpretations of God's word. However, most religious texts are taken to be sacred scripture directly or indirectly coming from the word of God. The Bible is taken to be holy and generally should be treated as such by their followers. Second, as a burden of proof response, if certain passages of the Bible are fabricated or misinterpretations, then who is to deny that the entire Bible is also fabricated or is a misinterpretation? The entire Bible itself could very well have been produced as merely a cultural by-product, 
as a misinterpretation, as a concoction constructed by false witnesses, etc. A theist making the move to say that the problematic passages are merely cultural by-products, misinterpretations, that they are produced by a false witness, etc., opens the floodgates for this type of criticism. Therefore, in this circumstance, the theist needs to provide a criterion that justifiably determines when a passage is really and accurately from God or not. The burden of proof squarely falls on the theist for this difficult task that somehow is able to show that the immoral commands did not really come from God but other ethical commands, many of which are stated in the same authored book or chapter as the supposedly inaccurate immoral mandates, actually did come from God. I take it that this is a significant and difficult burden of proof. To note, the theist may respond that since God is omnibenevolent, only the moral commands are really from God while the immoral ones must be fabricated or must be misinterpretations. This is the criterion for separating legitimate holy passages from the illegitimate ones. However, the question at hand is whether the supposed omnibenevolent God gave immoral commands or not. If one states that the supposed God did not do so because he is omnibenevolent, then one has simply begged the question at hand.

A fourth objection is the canonical approach, whose main champion is the biblical scholar Brevard Childs $(1970,2006)$. This view claims that eliminating certain passages in the Bible as in the moral reading approach while keeping certain others is a distortion of the Biblical witness and it demeans the very essence of scripture. Therefore, one must take the entire canonical evidence into consideration and understand individual passages in a wider context. One must keep in mind the meaning and import of the biblical texts as a whole when interpreting them. By looking at the integrated big picture and gathering a total contextual impression, the purportedly ethically problematic passages of the Bible can be seen in a different light and interpretation than if they were examined in isolation. For example, the supposedly ethically problematic acts of the Patriarchs in the book of Genesis, when examined based on the canonical approach and bringing in the book of Psalms (Psalms $105 \&$ 106), can be seen as a lesson of redemption and God's purposes of salvation rather than being seen as an instance of certain Biblical characters having supposedly morally suspect intentions.

The first problem with this approach is that even if there is a systematic moral message in the Bible, an omnibenevolent God under no circumstances should explicitly still order for genocide, rape, 
revenge killings, misogyny, and the like. There appears to be no excuse for uttering such commands from an entity that is omnibenevolent, especially when people actually did perform the relevant heinous acts in the specified situations. Systematization of overarching moral themes should have been reached through other more palatable means. Second, the canonical approach requires the moral tenets of the entire Bible to have a substantial degree of coherence and consistency, but the Bible is notoriously anything but that (Davies 2010: 92-97). There is not one unified moral vision to the Bible or an overarching general theme. Too many contradictions exist for coherence and systematization. For example, numerous instances of apparently immoral commands that directly contradict many of the teachings of, for instance, Jesus have already been examined above. Given the moral contradictions of peace and violence in the Bible, the Christian scholar Eryl Davies notes in light of the canonical approach that, 'Individual traditions are often suppressed in the interest of maintaining a coherent whole, and the plurality of perspectives is dissolved in an attempt to achieve a harmony where patently no harmony exists' (2010: 94). For example, notice the striking and contradicting passages in the Bible, where the first predicts a reign of peace and the second is a demand for war:

They shall beat their swords into ploughshares and their spears into pruning hooks (Isaiah 2:4).

Beat your ploughshares into swords and your pruning hooks into spears (Joel 3:10).

Fifth is the paradigmatic approach, where one of the main proponents is the biblical scholar Christopher Wright (2004). This view generally claims that the Old Testament provides people with broad general moral principles that may help people in their decision-making. Such broad rules are to be understood as general models that human beings are to apply in the particular moral scenarios people may encounter in their everyday moral lives. Therefore, people should not pay attention to the specific laws and customs of the Old Testament, but they should focus on the general principles that underlie them. As with the canonical approach, there is an alternate underlying meaning and interpretation to the passages. For example, the law of the Jubilee year (Lev 25:8-55) that forfeited property to a creditor must periodically be restored to the debtor - is no longer applied in today's age. However, from this passage 
people may garner the underlying principle that they should show compassion to the poor.

The response, similar to the canonical approach, is that even if there is some kind of underlying benevolent message to the problematic passages of the Bible, an omnibenevolent God still should not explicitly state orders for pillaging, plundering, and ethnic cleansing. Underlying general principles should not be implicitly given by an omnibenevolent God by explicitly stating what are appalling moral injunctions, especially since people actually did perform the licentious acts in the relevant situations. Surely a truly omnibenevolent God would have used other means for moral education. Therefore, the inconsistency remains. For instance, it specifically may be asked what the underlying moral principle is to a particular problematic case. Take for instance the command for the genocide of the Canaanites. While Wright acknowledges the moral revulsion from reading the relevant chapters, he claims that the general underlying message is one of salvation and 'universal blessing' for the people of God. There is an underlying alternative meaning and interpretation to it all. However, what about the blessing of the slaughtered Canaanites who were also made in God's image? Doesn't God love all his children? Also, the supposed underlying principles or meanings to many passages still do not justify the explicit commands contained in those passages that were acted upon. ${ }^{6}$ Bringing about the purported underlying moral theme of salvation and blessing for God's people and not for others by in part commending genocide and rape is severely morally unacceptable and should not have been ordered by a supposedly omnibenevolent God. An omnibenevolent God could have attained his supposed underlying message through more ethical means. Hence, the contradiction remains. It seems that in order to be saved, one potential avenue that may be taken is that the paradigmatic approach may then revert to the canonical approach. However, the canonical approach, as has been previously shown, is itself problematic.

On a more extreme note, philosophers such as Richard Swinburne (2011), William Lane Craig (2007), and Copan (2008) contend that things like genocide in the Bible are morally justified since this either helped the Israelites avoid becoming spiritually corrupted by other polytheistic

\footnotetext{
${ }^{6}$ Commands for genocide were acted upon, but they may not have been completely carried out to fulfilment in all cases. For instance, the ancient Jewish people did kill many Canaanites, but they did not kill all of them.
} 
nations or the other nations deserved punishment for their sinful lives. For example, Swinburne writes that ethnic and racial extermination is justified in that it is used to 'preserve the young monotheistic religion of Israel from lethal spiritual infection by the polytheism of the Canaanites ... ' (2011: 224). Craig says, 'So whom does God wrong in commanding the destruction of the Canaanites? Not the Canaanite adults, for they were corrupt and deserving of judgment.' (2007)

In ethics it is exceptionally difficult to justify genocide and ethnic cleaning for any reason. To claim the permissibility of wiping out a whole people, women, and children is beyond serious consideration. In fact, in philosophy I have only read theist philosophers of religion, who supposedly believe in the teachings of Jesus, try to do this. Regarding Craig's claim that the extermination of many races and ethnicities was deserved since they committed so many ostensible sins, what were taken at the time to be common immoral acts of relevant non-Jewish ethnicities were idolatry, incest, adultery, prostitution, child sacrifice, homosexuality, and bestiality. The most serious of these is child sacrifice. Let us put this to the side for now and discuss the other so-called sins. We will return and discuss child sacrifice later.

Killing others because they practice a different religion, partake in incest, prostitution, adultery, homosexuality, and bestiality is not justified. Assuming that capital punishment is justified, people have an individual right to life; a right that cannot be so easily taken away via capital punishment except in the most egregious of circumstances such as in cases of premeditated murder. However, the so-called sins at hand are not even close to being crimes that are worthy of capital punishment. The mass genocide is not warranted for the purported sins in question. Furthermore, what would Jesus do; a man who kept the company of prostitutes and corrupt tax collectors? Jesus, arguably the most influential and most powerful moral philosopher in the history of ethics, famously also forgave a criminal who was dying next to him on a cross, and while hanging on the cross from nails through his body embedded in wood, he said in regard to his Roman persecutors (this is truly remarkable), 'Father, forgive them; for they know not what they are doing' (Luke 23:34). The right thing to do for those sinners, such as the Canaanites who probably were not even aware that their acts were supposed sins, is to try to change them and teach them the error of their ways with great patience (Morriston 2009). It is not to order for them to be killed: men, women, infants, animals, and all. 
Concerning child sacrifice, does this justify capital punishment in the form of genocide? What is curious in this case is that God also commands for child sacrifice for his people: 'I defiled them through their very gifts, in their offering up all their firstborn, in order that I might horrify them, so that they might know that I am the Lord.' (Ezek 20:26) However, regardless of this fact, even though child sacrifice warrants capital punishment, it only ethically warrants it for those who perform the sacrifice. To order that the right to life should be taken away for those who do not commit this crime, such as infants, and that they should be put to death in a mass genocide is egregiously morally wrong. It leads to a basic mistake in ethics of incorrectly and knowingly placing the moral blame and moral punishment on the wrong agents, which leads to disastrous, unethical, and horrendous effects.

Recall that Swinburne claims that the orders for genocide are required in order to protect the young spiritual minds of the Israelites so that they are not morally corrupted. To note, one of Hitler's main justifications for the Holocaust was similarly due to the reason that the Jewish people supposedly were immoral, and they were corrupting non-Jewish Germans. Imagine a third world country in the modern world that was largely polytheistic, but now they have widely adopted Christianity. One of their neighbouring countries practices a polytheistic religion which allows for things like bestiality, prostitution, child sacrifice, etc. This new Christian country then says that they are going to attempt to wipe out this other polytheistic nation not because they commit immoral acts, but rather, only so they do not themselves become spiritually corrupted from their neighbours. Even though it is the case that the polytheistic nation should be stopped for performing things like child sacrifice, is the moral thing to do in this case to order the killing of all the people of this polytheistic nation including the children who themselves would have been sacrificed? Is such a commendation of genocide warranted just to stop one's own people from being morally influenced and corrupted? This is clearly a perversion of morality, to order for a command of genocide in this case, especially since you do not need to kill their infants in order to stop your own people from being corrupted. Also, it makes a fundamental error in ethics of knowingly and falsely attributing moral blame on the children, some of whom would have been sacrificed themselves. Furthermore, what would Jesus do in this case? Patient moral education, love, and tolerance of sinners who may not even know the error of their ways so that they might find moral redemption would 
be the remedy. Jesus would especially find orders for the killing of the babies of the polytheistic nation and taking away their right to life to be ethically repulsive. For the above reasons and via argument by analogy, Swinburne's justification for the many genocides is also not warranted. ${ }^{7}$

Finally, theists such as Alvin Plantinga (2011), Michael Bergmann (2009), and Mark Murphy (2011) make the appeal to ignorance. This is where humans ignorantly perceive apparent problematic moral passages in scripture, but such passages are really not problematic. God works in mysterious ways, and human beings are ignorant of his 'big picture, purposes, and final educational aims. One cannot know God's ultimate plan or purpose similar to how a small child cannot fully understand her parents' intentions, but one must be assured that the ultimate plan is such that somehow no logical contradiction exists. Notice that the appeal to ignorance for the moral epistemological argument does not directly demonstrate that there is no contradiction as all the previously entertained theistic objections in this paper attempt to do, but rather it functions in a more indirect fashion. In the case at hand, the theist cannot explicitly state why it is not the case that there is a contradiction. Rather, God works in mysterious ways, and God's plan has it set up such that it is not the case that there is a contradiction even though we do not know why.

However, the fact that God works in mysterious ways does not necessarily mean that no contradiction exists. For, in making such a move, the theist does not take into account that it could equally be the case that even though the supposed God works in mysterious ways, the apparent contradiction still persists. It does not immediately follow from the appeal to ignorance that the contradiction has been eliminated. The property of 'working in mysterious ways' does not in-and-of-itself necessarily lead to the fact that the supposed contradiction must then be eradicated. Rather, at this first initial stage of assessing the appeal to ignorance and the property 'working in mysterious ways', it is equally rational to conclude that there still may be a supposed contradiction or there may not be one, and thus, an agnosticism is warranted regarding the efficacy of the appeal to ignorance. It is equally rational that God works in mysterious ways always towards good or perhaps, on the other hand, sometimes towards evil. If the theist then claims that the supposed contradiction must be eradicated if God works in mysterious ways

\footnotetext{
${ }^{7}$ For further reasons against Swinburne, see (Morriston 2011).
} 
because the purported God is omnibenevolent, then this is once again begging the question. On the other hand, the fact remains that given all the concrete religious textual evidence discussed above, there is a rather sizable and significant level of justification that the supposed existence of an omnibenevolent God does at times lead to an apparent contradiction as stated in the moral epistemological argument. There is significant evidence that if God exists, at times God purportedly does issue immoral decrees. Due to this bevy of direct tangible evidence, this places a heavy and substantial burden of proof on the theist who makes the appeal to ignorance to show in a non-question begging way that even though God works in mysterious ways, the purported God and his existence in all the problematic passages eliminates rather than upholds the supposed contradiction. While this burden of proof counter as presently stated in-and-of-itself may be sufficient to respond to the appeal to ignorance, what is even stronger, this burden that the theist bears can never be met by the theist who makes the appeal to ignorance precisely because God works in mysterious ways, and no one can know or understand his plans; an understanding that is required in order to meet the burden.

\section{CONCLUSION}

I have newly articulated an argument for atheism called, 'the moral epistemological argument'. I have laid out the theoretical basis of how it is a logical contradiction contention and how it differs from other logical contradiction arguments such as the problem of evil and the problem of hell. I have supported it with problematic ethical religious passages, and I have defended this argument from potential counters from philosophers and religious scholars. Some of the attempts particularly from religious scholars have not been addressed generally by philosophers, and some of them may not even be known in many philosophical circles. Furthermore, at times I have provided novel rebuttals of the various ways theists may try to object to the moral epistemological argument. All in all, given the moral epistemological argument, I conclude that God does not exist. 


\section{BIBLIOGRAPHY}

Adams, Marilyn McCord. 1993. 'The Problem of Hell: A Problem of Evil for Christians', in Eleonore Stump (ed.), Reasoned Faith (Ithaca: Cornell University Press), pp. 301-327

Albright, W. F. 1940. From the Stone Age to Christianity: Monotheism and the Historical Process (Baltimore: The Johns Hopkins Press)

Antony, Louise. 2011. 'Does God Love Us?', in Michael Bergmann, Michael J. Murray, and Michael C. Rea (eds), Divine Evil? The Moral Character of the God of Abraham (Oxford: Oxford University Press), pp. 29-46

Arnold, T. 1844. Sermons. Vol 2, 3rd Edition (London: Rivingtons)

Barr, James. 1993. Biblical Faith and Natural Theology (Oxford: Clarendon Press)

Bergmann, Michael. 2009. 'Skeptical Theism and the Problem of Evil', in Thomas

P. Flint and Michael C. Rea (eds), The Oxford Handbook of Philosophical Theology (Oxford: Oxford University Press), pp. 374-399

Bergmann, M., Michael J. Murray, and Michael C. Rea (eds). 2011. Divine Evil? The Moral Character of the God of Abraham (Oxford: Oxford University Press) pp. 1-21

Childs, Brevard. 1970. Biblical Theology in Crisis (Philadelphia: The Westminster Press)

Childs, Brevard. 2006. 'The Canon in Recent Biblical Studies: Reflections on an Era', in C.G. Bartholomew (ed.), Canon and Biblical Interpretation (Milton Keynes: Paternoster Press), pp. 32-56

Copan, Paul. 2008. 'Is Yahweh a Moral Monster? The New Atheists and Old Testament Ethics', Philosophia Christi, 10: 7-37

Copan, Paul. 2011. Is God a Moral Monster? (Grand Rapids, MI: Baker Books)

Craig, William Lane. 2007. 'Slaughter of the Canaanites', Reasonable Faith with William Lane Craig. Available at: <http://www.reasonablefaith.org/ slaughter-of-the-canaanites $>$ [accessed 12/6/13]

Dawkins, Richard. 2006. The God Delusion (Boston: Houghton Mifflin)

Davies, Eryl. 2010. The Immoral Bible (London: T \& T Clark International)

Dennett, Daniel. 2006. Breaking the Spell: Religion as a Natural Phenomenon (New York: Viking)

Fales, Evan. 2011. 'Satanic Verses: Moral Chaos in Holy Writ', in Michael Bergmann, Michael J. Murray, and Michael C. Rea (eds), Divine Evil? The Moral Character of the God of Abraham (Oxford: Oxford University Press), pp. 91-108

Goodwin, Geoffrey and John Darley. 2008. 'The Psychology of Meta-ethics: Exploring Objectivism', Cognition, 106: 1339-1366

Harris, Sam. 2006. Letter to a Christian Nation (New York: Alfred A. Knopf)

Hitchens, Christopher. 2007. God is Not Great: How Religion Poisons Everything (New York: Hachette Book Group)

Holy Bible. 1983. (Dallas, TX: Word Publishing) 
Maurice, F. G. 1855. Patriarchs and Lawgivers of the Old Testament, 2nd Rev. Edition (Cambridge: Macmillan and Son)

Morriston, Wes. 2009. 'Did God Command Genocide? A Challenge to the Biblical Inerrantist', Philosophia Christi, 11: 7-26

Morriston, Wes. 2011. 'Comments on “What Does the Old Testament Mean?", in Michael Bergmann, Michael J. Murray, and Michael C. Rea (eds), Divine Evil? The Moral Character of the God of Abraham (Oxford: Oxford University Press), pp. 226-231

Morriston, Wes. 2012. 'Ethical Criticism of the Bible: The Case of Divinely Mandated Genocide', Sophia, 51: 117-135

Murphy, Mark. 2011. 'God Beyond Justice', in Michael Bergmann, Michael J. Murray, and Michael C. Rea (eds), Divine Evil? The Moral Character of the God of Abraham (Oxford: Oxford University Press), pp. 150-167

Nineham, Dennis. 1976. The Use and Abuse of the Bible (London and Basingstoke: The Macmillan Press Ltd)

Plantinga, Alvin. 2011. 'Comments on "Satanic Verses: Moral Chaos in Holy Writ”, in Michael Bergmann, Michael J. Murray, and Michael C. Rea (eds), Divine Evil? The Moral Character of the God of Abraham (Oxford: Oxford University Press), pp. 109-114

Qur'an. 1997. Edited by M. Z. Kahn (Northampton, MA: Interlink Publishing Group)

Rodd, Cyril. 2001. Glimpses of a Strange Land (Edinburgh: T. \& T. Clark)

Russell, Bertrand. 1927. 'Why I am not a Christian', reprinted in Bertrand

Russell, Why I Am Not a Christian, ed. by Paul Edwards (New York: Simon and Schuster, Inc., 1967)

Swinburne, Richard. 2011. 'What Does the Old Testament Mean? Divine Evil? The Moral Character of the God of Abraham. Ed. by Bergmann, M., Murray, M., and Rea, M. Oxford: Oxford University Press, 209-225.

Inwagen, Peter van. 2011. 'Comments on 'The God of Abraham, Isaac, and Jacob." Divine Evil? The Moral Character of the God of Abraham. Ed. by Bergmann, M., Murray, M., and Rea, M. Oxford: Oxford University Press, 79-84.

Wellhausen, Julius. 1885. Prolegomena to the History of Israel. Trans. by Black, J.S. and Menzies, A. Edinburgh: A. \& C. Black.

Wright, Christopher. 2004. Old Testament Ethics for the People of God. Leicester: Inter-Varsity Press. 